\title{
DETERMINATION OF VISUAL ACUITY AND VISUAL AXIS OF BROWN- MARBLED GROUPER, Epinephelus fuscoguttatus TO DEVELOP A DEMAND FEEDING SYSTEM
}

\author{
Nai Han Tan ${ }^{1}$, Rian Freddie Firdaus ${ }^{2}$ and Yukinori Mukai ${ }^{2 *}$ \\ ${ }^{1}$ Borneo Marine Research Institute, Universiti Malaysia Sabah, 88400, Kota Kinabalu, Sabah, Malaysia \\ ${ }^{2}$ Institute of Oceanography and Maritime Studies, International Islamic University Malaysia, Bandar Indera \\ Mahkota, 25200 Kuantan, Pahang, Malaysia \\ *Corresponding author (email: mukai9166@gmail.com)
}

\begin{abstract}
The visual acuity and visual axis of juvenile brown-marbled grouper, Epinephelus fuscoguttatus were determined to get the understanding of their vision in order to develop a demand feeding system. Three juveniles were anaesthetised with MS222 and fixed in Bouin's solution. The left retina of each juvenile was cut into nine regions - the dorso-nasal (DN), dorsal (D), dorso-temporal (DT), nasal $(\mathrm{N})$, bottom $(\mathrm{B})$, temporal $(\mathrm{T})$, ventro-nasal $(\mathrm{VN})$, ventral $(\mathrm{V})$, and ventro-temporal $(\mathrm{VT})$. The specimens were embedded in paraffin, cut into $6 \mu \mathrm{m}$ thick tangential sections, and stained with haematoxylin-eosin. The density of cone cells $\left(0.01 \mathrm{~mm}^{2}\right)$ in each region was counted in the stained sections. Visual acuity was calculated using cone cell densities and lens diameter. The highest cone cell densities of each of the juveniles were 359 (bottom, B), 394 (temporal, T), and 380 cells $/ 0.01 \mathrm{~mm}^{2}$ (temporal, T), respectively. The estimated visual acuities were $0.068-0.081$ in those regions, respectively. These results showed that the visual axis of brown-marbled grouper juveniles was forward. Therefore, the position of the target switch of demand feeding system was set at $2 \mathrm{~cm}$ below the water surface.
\end{abstract}

\begin{abstract}
ABSTRAK Dalam usaha membangunkan sistem permintaan makan untuk juvana kerapu harimau, Epinephelus fuscoguttatus, ketajaman dan paksi penglihatan juvana kerapu harimau telah ditentukan untuk mendapatkan pemahaman asas penglihatan. Tiga juvana kerapu harimau dibius dengan MS222 dan diawet dalam larutan Bouin. Retina kiri setiap juvana telah dipotong kepada sembilan bahagian - dorso-nasal $(\mathrm{DN})$, dorsal (D), dorso-temporal (DT), nasal (N), dasar (B), temporal (T), ventro-nasal (VN), ventral (V) dan ventro-temporal (VT). Spesimen-spesimen tersebut ditanam dalam parafin, dipotong secara tangen setebal $6 \mu \mathrm{m}$, dan diwarnakan dengan haematoxylin-eosin. Ketumpatan sel-sel kon $\left(0.01 \mathrm{~mm}^{2}\right)$ dalam setiap bahagian telah dikira. Ketajaman penglihatan dikira menggunakan ketumpatan sel-sel kon dan diameter kanta. Ketumpatan sel-sel kon tertinggi bagi setiap juvana kerapu harimau adalah 359 (dasar, B), 394 (temporal, T) dan $380 \mathrm{sel} / 0.01 \mathrm{~mm}^{2}$ (temporal, T) masing-masing. Anggaran ketajaman penglihatan adalah 0.068-0.081 dalam bahagian-bahagian tersebut. Keputusan ini menunjukkan bahawa paksi penglihatan juvana kerapu harimau adalah ke hadapan. Oleh itu, kedudukan suis sasaran sistem permintaan makan ditetapkan pada $2 \mathrm{~cm}$ di bawah permukaan air.
\end{abstract}

(Keywords: Brown-marbled grouper; Epinephelus fuscoguttatus; visual acuity; visual axis; demand feeding system)

\section{INTRODUCTION}

Visual acuity is the ability of eye to see the objects clearly at a given distance especially close distance [1]. Visual acuity is also defined as the smallest angle formed at the eye by two objects perceived separately; the two objects remain resolvable on the retina [2, 3 and 4]. The acuity in fish improves with growth as larger image is produced by large eye [5]. On the other hand, visual axis is defined as the direction of the sharpest vision [6]. It is an imaginary line from the centre of the high cone density area to the centre of the lens [7]. Visual axis can be determined by the region with maximum cone cell counts in the retina [8, 9 and 10]. The visual axis is correlated to the feeding behaviour and habitat of fish species [7 and 11]. Each fish species has different visual axis, thus each species must be studied to determine the target switch position in developing suitable feeding devices.

Demand feeding is one of the feeding methods in aquaculture. The demand feeding system requires the fish to turn on a feeder switch in 
order to gain access to food [12]. This method has several advantages because the fish can eat whenever they are most motivated to feed. The technology can thus improve fish growth, minimise feed loss, and reduce water pollution [13].

Brown-marbled grouper, Epinephelus fuscoguttatus, which occurs widely in the Asian Pacific region, is one of the important species of groupers [14]. It has high value of price and demand in Southeast Asia [15]. With the current status of grouper aquaculture in Malaysia, this species has great potential for further expansion due to several factors including improvements in technology and strong support from the local government [16]. The current most urgent issue facing the aquaculture industry in Malaysia is the seed production. Feeding methods are important because fish change their feeding habit and pattern with growth. Hence, feeding methods should also be adapted following fish growth. Therefore, in this study, a suitable demand feeding device for groupers was developed. In order to develop the new demand feeding system for brown-marbled grouper, Epinephelus fuscoguttatus juveniles, the position of the target switch in the demand feeding system can be decided based on the visual axis.

\section{MATERIALS AND METHODS}

To count the densities of cone cells for calculating the visual acuity of brown-marbled grouper, three juveniles were anaesthetised with MS222 and fixed in Bouin's solution for $24 \mathrm{~h}$. Then, the samples were preserved in $70 \%$ ethanol. The left retina of each juvenile was cut into nine regions (Figure 1).
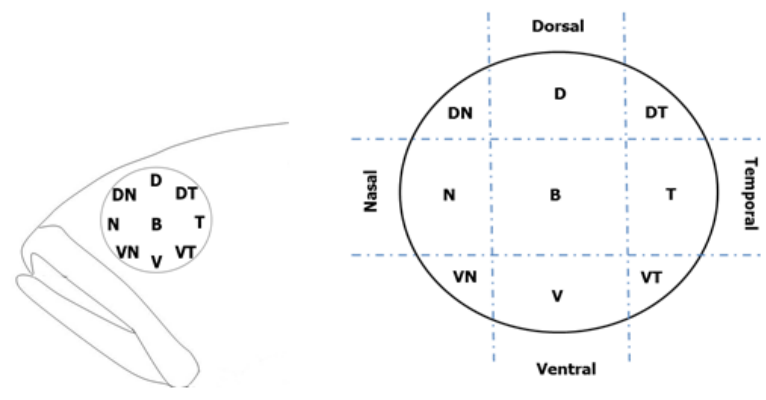

Figure 1. Schematic diagram of the retina used for histological examination
The specimens were embedded in paraffin, cut into $6 \mu \mathrm{m}$ thick tangential sections, and stained with haematoxylin-eosin. The density of cone cells (number of cone cells in $0.01 \mathrm{~mm}^{2}$ ) in each region was counted in the stained sections under a light microscope. Visual acuity (VA) was calculated using cone cell densities and lens diameter based on the following formula:

$$
\sin \alpha \approx \alpha=\frac{1}{f}\left[\frac{0.1 \times(1+0.25) \times 2}{\sqrt{n}}\right]
$$

where, $\alpha=$ minimum separable angle, $f=$ focal length of the lens $(\mathrm{mm}), 0.25=$ ratio of shrinkage caused by fixation with Bouin's solution, and $n=$ number of cones per $0.01 \mathrm{~mm}^{2}$ in the retinal region. The focal length of the lens was estimated by multiplying the lens radius by Matthiessen's ratio (2.55; Matthiessen, 1880) [17]. Visual acuity was then calculated using the following formula:

$$
V A=\frac{1}{\alpha} \times \frac{2 \pi}{360} \times \frac{1}{60}
$$

\section{RESULTS}

The visual acuity and visual axis of brownmarbled grouper juveniles were assessed through histological methods. Histological sections of the nine regions of the retina were examined to count the density of cone cells. The density of cone cells in each region was counted in the stained sections.

Figure 2a showed the tangential section of the retina in the temporal $(\mathrm{T})$ region. The cones were arranged in square cone mosaic pattern where a central single cone was surrounded by four double cones. The double cones were oriented at $90^{\circ}$ from one another (Figure 2b). The corner single cones were absent in each region of the retinae observed.

The cone cell densities of three brown-marbled grouper juveniles ( $a, b$, and $c$ ) were shown in Figure 3. The cone density varied among the regions of the retinae of the samples examined. The highest cone densities (cells $/ 0.01 \mathrm{~mm}^{2}$ ) of each juvenile were as follows: $a, 359$ (bottom, B); $b, 394$ (temporal, T); and $c, 380$ (temporal, T). 

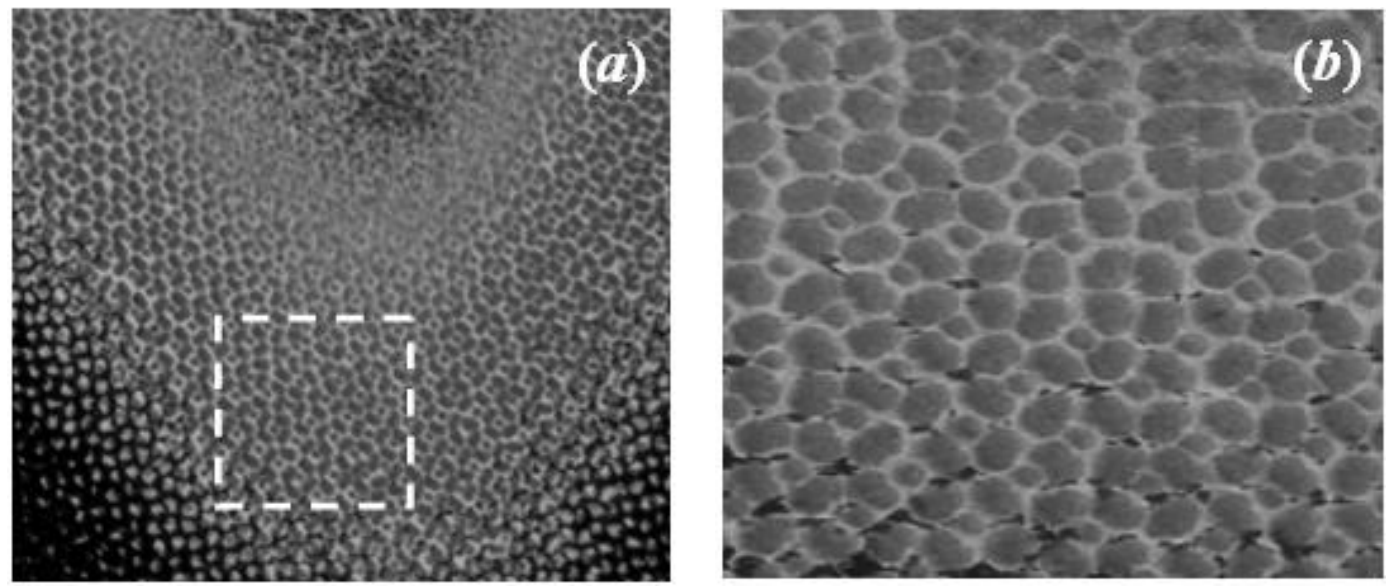

Figure 2. Tangential section of the retina of brown-marbled grouper juvenile. (a) The high density region; temporal region (scale bar: $5 \mu \mathrm{m}$ ). (b) The square cone mosaic pattern arrangement of the cone cells
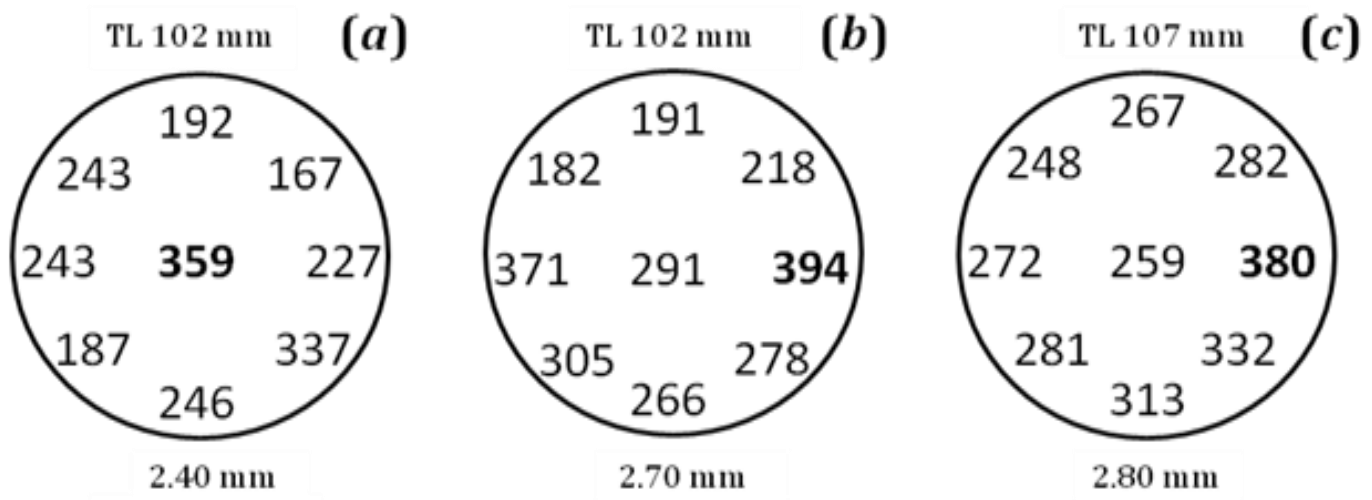

(Lens diameter)

Figure 3. Cone cell densities (number of cells per $0.01 \mathrm{~mm}^{2}$ ) of the three brown-marbled grouper juveniles $(a, b$, and $c)$
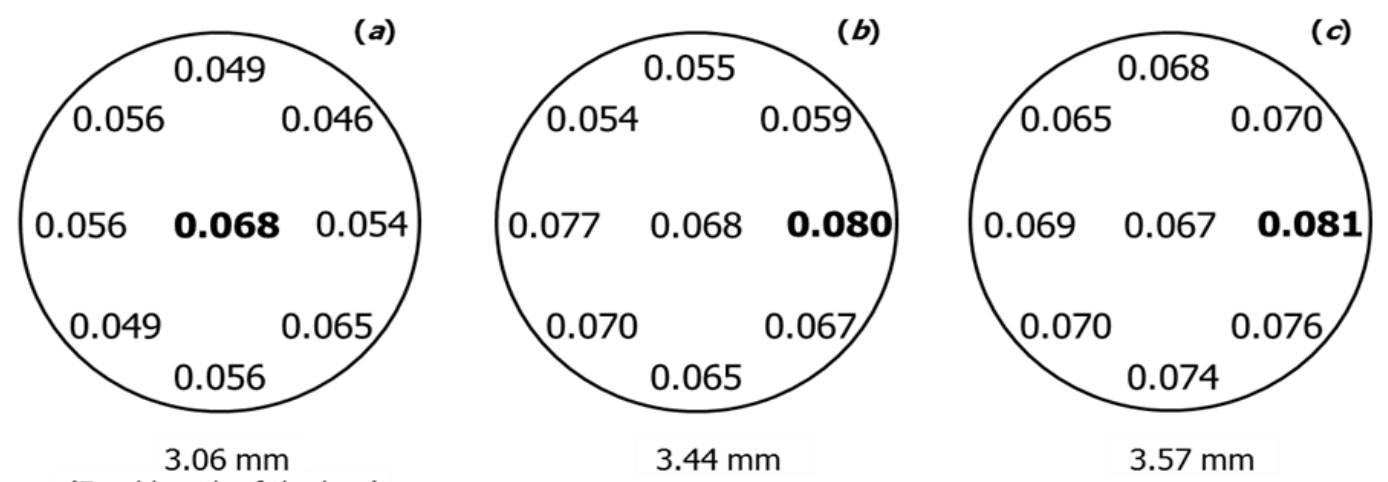

(Focal length of the lens)

Figure 4. Visual acuities of the three brown-marbled grouper juveniles $(a, b$, and $c)$

Next, the estimated visual acuities were shown in Figure 4. The estimated visual acuities were as follows: $a, 0.068 ; b, 0.080$; and $c, 0.081$. These results showed that the visual axes of brownmarbled grouper juveniles were forward. 


\section{DISCUSSION}

In order to develop a demand feeding system to which brown-marbled grouper juveniles visually responded, the visual acuity and visual axis of the juveniles were determined to get the understanding of their vision. In this study, the target switch was located $2 \mathrm{~cm}$ below the water surface with the consideration of the fish behaviour, visual acuity, and visual

axis.

The feeding behaviour of brown-marbled grouper juveniles was observed through video recording. The searching for food was the integral part of fish overall activity. Before feeding, the juveniles were observed swimming at the bottom layer of the water column in the tank. When they were hungry, a few juveniles swam up to the upper layer of water column and close to the water surface. All juveniles followed and started to swim around the target switch. While swimming around the target switch, their eyes were focused on the switch. The target switch detected the presence of juveniles when they interrupted the infrared light beam. The food container then rotated and feed was distributed. This behaviour continued until the juveniles were full. After that, the juveniles swam down to the bottom of the tank and swam slowly.

The visual axis of the brown-marbled grouper, Epinephelus fuscoguttatus was forward as shown from the measurement of cone cell densities. The maximum cone cell counts were in the temporal region of the retina. Same like Epinephelus septemfasciatus, the maximum cone cell counts are also in the temporal region. This visual axis is typically related to the feeding behaviour and habitat of fish species [7 and 11]. In the wild, grouper juveniles are usually found in sea grass bed, while grouper of other life stages occur on the coral reefs with clear water, rocky reefs or in the estuaries [18]. Groupers exhibit a tendency to take food available in front of them. In this study, it was observed that, in the aquarium, the eyes of the brown-marbled grouper focused on the objects in front of them. The same finding was found when this behaviour was observed in the video recording of brown marbled grouper.

\section{CONCLUSION}

Based on the histological results obtained, the visual axes of brown-marbled grouper juveniles were forward. The highest cone density was found in the temporal part of the retinae, which ranged from 227 to 394 cells $/ 0.01 \mathrm{~mm}^{2}$. The estimated visual acuities in temporal were in the range of $0.054-0.081$. These results provide the fundamental understanding on the perception towards target switch by brown-marbled grouper.

\section{ACKNOWLEDGMENTS}

This study was supported by the e-Science Fund (05-01-08-SF1002) of the Ministry of Science, Technology and Innovation of Malaysia.

\section{REFERENCES}

1. Nakamura E. L. (1968). Visual acuity of two tunas, Katsuwonus pelamis and Euthynnus affinis. Copeia 1968(1): 41 - 49.

2. Neave D. A. (1984). The development of visual acuity in larval plaice (Pleuronectes platessa L.) and turbot (Scophthalmus maximus L.). Journal of Experimental Marine Biology and Ecology 78: 167 - 175.

3. Douglas R. H. and Hawryshyn C. W. (1990). Behavioural studies of fish vision: an analysis of visual capabilities. In: The Visual System of Fish. (eds. Douglas R. H. and Djamgoz M. B. A.) Chapman and Hall, London, pp. 374 - 418.

4. Evans B. I. (2004). A fish's eye view of habitat change. In: The Senses of Fish: Adaptations for the Reception of Natural Stimuli. (eds. von der Emde G., Mogdans J. and Kapoor B. G.) Narosa Publishing House, New Delhi, pp. 1 - 30.

5. Fernald R. D. (1991). Teleost vision: seeing while growing. Journal of Experimental Zoology Supplement 5: 157 - 180.

6. Somiya H. and Tamura T. (1973). Studies on the visual accommodation in fishes. Japanese Journal of Ichthyology 20(4): 193 - 206.

7. Tamura T. (1957). A study of visual perception in fish, especially on resolving power and accommodation. Bulletin of the Japanese Society of Scientific Fisheries 22(9): 536 - 557. 
8. Collin S. P. and Pettigrew J. D. (1988a). Retinal topography in reef teleosts. I. Some species with well-developed areae but poorly-developed streaks. Brain, Behaviour and Evolution 31: 269 - 282.

9. Collin S. P. and Pettigrew J. D. (1988b). Retinal topography in reef teleosts. II. Some species with prominent horizontal streaks and high density areae. Brain, Behaviour and Evolution 31: 283 - 295.

10. Shand J., Chin S. M., Harman A. M., Moore S. and Collin S. P. (2000). Variability in the location of the retinal ganglion cell area centralis is correlated with ontogenetic changes in feeding behaviour in the black bream, Acanthopagrus butcheri (Sparidae, Teleostei). Brain, Behaviour and Evolution 55: 176 - 190 .

11. Kino M., Miyazaki T., Iwami T. and Kohbara J. (2009). Retinal topography of ganglion cells in immature ocean sunfish, Mola mola. Environmental Biology of Fish 85: 33 - 38.

12. Furukawa K. (2001). Demand feeding of red sea bream. In: Demand-feeding in fish. (eds. Tabata M. and Koseikaku K.) Tokyo, Japan, pp. 127.

13. Azzaydi M., Madrid J. A., Zamora S., Sanchez-Vazquez, F. J. and Martinez F.J. (1998). Effect of three feeding strategies (automatic, ad libitum demand-feeding and time-restricted demand-feeding) on feeding rhythms and growth in European sea bass (Dicentrarchus labrax L.). Aquaculture 163: 285 - 296.

14. Randall J. E. and Heemstra P. C. (1991). Revision of Indo-Pacific groupers (Perciformes: Serranidae: Epinephelinae), with descriptions of five new species. IndoPacific Fishes 20: 1 - 332.

15. James C. M., Al-Thobaiti S. A., Rasem B. M. and Carlos M. H. (1998). Comparative growth of brown-mabled grouper Epinephelus fuscoguttatus (Forsskal) and camouflage grouper E. polyphekodion (Bleeker) under hatchery and growout culture conditions. Asian Fisheries Science 11: 133 147.

16. Hussin M. A., Nik Haiha N. Y., Ahmad D. O., Che Utama C. M. and Mohd Fariduddin
O. (2008). Status and prospects of grouper aquaculture in Malaysia. In: The Aquaculture of Groupers. (eds. Liao I. C. and Leano E. M.) Asian Fisheries Society, World Aquaculture Society, The Fisheries Society of Taiwan and National Taiwan Ocean University, Taiwan, pp. 155 - 175.

17. Matthiessen L. (1880). Untersuchungen uber den Aplanatismus die Periscopie der Krystallinsen in den Augen der Fische. Pflugers Arch. Gesamte Physiol. Menschen Tiere. 21: 287 - 307. As cited in: Neave D. A. (1984). The development of visual acuity in larval plaice (Pleuronectes platessa L.) and turbot (Scophthalmus maximus L.). Journal of Experimental Marine Biology and Ecology 78: 167 - 175.

18. Heemstra P. C. and Randall J. E. (1993). FAO Species Catalogue Vol. 16. Groupers of the World (Family Serranidae, subfamily Epinephelinae), An Annotated and Illustrated Catalogue of the Grouper, Rockcod, Hid, Coral Grouper and Lyretail Species Known to Date. Food and Agriculture Organization of the United Nations. Rome, I, II. 